In the penultimate chapter, Byrne pushes her subjects further, asking them to reflect on their sense of national identity. Here she suggests that her subjects' accounts of their own life stories are closely intertwined with their sense of what a national, collective narrative might be: 'As such, it was fluid and multiple' (p. 167). Her final chapter, written in 2005 , deals with the political implications of her pre-war fieldwork but here she admits why this reflexive work is unlikely to make the headlines. 'The book', she writes, 'has focused on how things are done as a preliminary move towards working out how they might be undone'. However, she leaves readers with the certainty that well-meaning white people cannot evade 'race' by thinking it has nothing to do with them.

\title{
references
}

Vron Ware

Frankenberg, R. (1993) White Woman, Race Matters: The Social Construction of Whiteness, Minnesota: University of Minnesota Press.

Walters, N. (1999) The New Feminism, London: Virago Press.

Walters, N. (2006) 'On a Wink and a Prayer' The Guardian, 14 July.

doi: $10.1057 / f r .2008 .15$

\section{The ethics of cultural studies}

Joanna Zylinska, Continuum, London and New York, 2005, ISBN 0-8264-7524-8£16.99 (Pbk)

Zylinska's is a very detailed and intricate consideration of ethics in cultural studies. Her analysis is framed within the history of cultural studies and some of the key texts; she draws on Derrida throughout but also engages with canonical authors such as Judith Butler, Donna Haraway, Stuart Hall, N. Katherine Hayles and Jean-Francois Lyotard, so that the reader can learn much about the field, as well as place Zylinska's work in a particular critical genealogy. However, the key contribution made by the book is to bring a new theoretical perspective to the issue of ethics in cultural studies - that of Levinas - and then to apply this to contemporary cultural problematics. It is important to understand that Zylinska's title refers to a very specific meaning of 'ethics' and this book is not about ethics in the generalized sense of moral principles; rather Zylinska proposes that cultural studies could gain much from a 'rigorous engagement' (p. 10) with the work of French philosopher Emmanuel Levinas for whom ethical responsibility comes from coming face-to-face with the Other. For Levinas, an encounter with the Other leads to an obligation without specific content; therefore ethics, in the sense Zylinska employs the term, cannot be a closed system filled with universal content. It is rather the response to alterity, the nature of which cannot be prescribed: 'The 
ethical condition arises out of this possibility of acknowledging and welcoming the alterity that, according to Levinas, is always already part of the self's experience' (p. 125). The author rightly points out that cultural studies has always been political but, for Zylinska, ethics is always prior to politics and necessary to the meaningful performance of politics. In the early chapters, she constructs a complex argument, full of paradoxes and clarifications, which posits that cultural studies has a strong ethical dimension and yet also lacks ethics. She writes: 'I hope my description of cultural studies' ethical engagement is performative' (p. 3); she seeks to both trace the ethical dimension within the discipline and propose a novel ethical element. Although the purpose of these opening chapters is to set up the argument that follows, they also raise questions about the relationship between ethics and politics and the place of both in cultural studies that remain open for the interested reader to consider further.

After two largely theoretical opening chapters, Zylinska expands on her themes with a series of quite short chapters that apply her approach to a wide range of contemporary cultural issues. Chapter three considers whether cultural studies can delineate an ethical response to moral panics around crime; chapter four investigates the media representation of $9 / 11$ and the possibility of an ethical response to issues of violence, debt and justice; chapter five looks at the UK Nationality, Immigration and Asylum Act (2002) and the biopolitics of immigration to produce, drawing on Butler, an 'ethics of bodies that matter'; chapter six struggles with ethics under duress in the case of the murder of Jews in Jedwabne, Poland, and the related issue of responsibility and forgiveness, particularly collective responsibility and forgiveness on a national scale; chapter seven considers the performance art of Stelarc and Orlan as 'the prosthetic ethics of welcome' (p. 123), opening oneself up to the Other and embracing difference in a way akin to Derridean hospitality; finally in chapter eight Zylinska turns to bioethics and cyberfeminism, positioning three mice (OncoMouse ${ }^{\mathrm{TM}}$, the nude mouse with a human ear growing from its back and the human hand gripping a computer mouse) as tools to think through a non-systemic feminist cyberbioethics. The chapters are all interesting and engaging, and Zylinska does not shy away from controversial subjects, but acknowledges in the text the difficulties of writing about certain events as well as the risks of making particular analytical juxtapositions. I was often left wishing for a few more pages in which to delve a little further into the issues but the concise nature of her treatment is a function of the broad scope of the book, as well as a clear focus on exploring the productivity of applying Levinas' model of ethics within the field of cultural studies. The range of material covered is impressive and would engage any reader who takes an interest in contemporary world events but the chapters are also amenable to be read separately by those with a specific interest in one of the topics. Indeed, Zylinska states her intention that this book may be accessible to readers who wish to dip into particular chapters and I think 
this is true but, to truly appreciate her thesis, particularly for those unfamiliar with Levinas, requires a careful reading of the first two chapters. The book makes an important and substantial contribution to cultural studies in the important field of ethics that nonetheless leaves readers with many avenues to pursue in their own thinking.

doi: $10.1057 /$ fr. 2008.18

Julie Palmer

\section{The feminist history reader}

Sue Morgan (editor); Routledge, London, 2006, 417p, ISBN 0-415-31810-6£20.99 (Pbk).

The Feminist History Reader features twenty-nine readings from the 1970s on, around the editor's view that four trajectories have characterized feminist historical theorizing: 'Bringing the feminist subject into view', 'Deconstructing the female subject: feminist history and "the linguistic turn"', 'Searching for the subject: lesbian history', 'Centres of difference: decolonizing subjects, rethinking boundaries', with a single reading in an 'Afterword'. Twenty-three selections are individual readings, while six are sets of shorter readings each representing a debate. The 'Introduction' presents the Reader's purpose as guiding 'the student of history' concerning, 'not... the historical "product" of feminist scholarship, but rather the main theoretical forms and directions it has taken... [its] internal debates and self-critical dialogue...'(p. 2). Many of the authors and selections will be familiar to advanced readers and are well chosen to represent important ideas and developments. The six sets of shorter readings really do convey the flavour of vibrant debates, communicate the important issues underpinning these and encourage engagement by readers, and are particularly useful for teaching and discussion purposes.

Clearly, each of the themes structuring the Reader has been important in feminist historical thinking, although there are additional areas which are not mentioned, surprisingly little discussion about how the four themes were arrived at and what alternatives were considered, nor consideration of the very different understandings of what theory 'is' which co-exist in feminist scholarship. The result is that the shape of the Reader has a rather 'it is so' feel, and given the openness with which other issues are considered in the 'Introduction', the absence of discussion here is a pity, as it could lead less advanced readers to (mistakenly) suppose that these four themes non-controversially cover the entire field of feminist theory in history.

Regarding all such readers, the relationship of the included material to 'the field' is crucial in reviewing the contents. And so what is the relationship between the 